\title{
Contaminant desorption during long-term leaching of hydroxide-weathered Hanford sediments
}

\author{
Aaron Thompson ${ }^{1}{ }^{*}$, Carl I. Steefel ${ }^{2}$, Nicolas Perdrial ${ }^{1}$ and Jon Chorover ${ }^{1}$ \\ ${ }^{1}$ Department of Soil, Water and Environmental Science, \\ University of Arizona, Tucson, AZ 85721 \\ ${ }^{2}$ Earth Sciences Division \\ Lawrence Berkeley National Laboratory, Berkeley, CA 94720 \\ \# Current address: Department of Crop and Soil Science, \\ University of Georgia, Athens, GA 30602
}

*Corresponding author E-mail: AaronT@uga.edu

BRIEF: Leaching waste-altered Hanford sediments with neutral solutions desorbs $\mathrm{Sr}$ from de novo waste-generated minerals and desorbs $\mathrm{Cs}$ from high-affinity ion exchange sites. 


\section{ABSTRACT}

Mineral sorption/co-precipitation is thought to be a principal sequestration mechanism for radioactive ${ }^{90} \mathrm{Sr}$ and ${ }^{137} \mathrm{Cs}$ in sediments impacted by hyperalkaline, high-level radioactive waste (HLRW) at the DOE's Hanford Site. However, the long-term persistence of neoformed, contaminant bearing phases after removal of the HLRW source is unknown. We subjected pristine Hanford sediments to hyperalkaline $\mathrm{Na}-\mathrm{Al}-\mathrm{NO}_{3}-\mathrm{OH}$ solutions containing Sr, Cs, and I at $10^{-5}, 10^{-5}$, and $10^{-7}$ molal, respectively, for 182 days with either $<10$ ppmv or 385 ppmv $p \mathrm{CO}_{2}$. This resulted in the formation of feldspathoid minerals. We leached these weathered sediments with dilute, neutral-pH solutions. After 500 pore volumes (PV), effluent $\mathrm{Sr}, \mathrm{Cs}, \mathrm{NO}_{3}, \mathrm{Al}, \mathrm{Si}$ and $\mathrm{pH}$ reached a steady-state with concentrations elevated above those of feedwater. Reactive transport modeling suggests that even after $500 \mathrm{PV}, \mathrm{Cs}$ desorption can be explained by ion exchange reactions, whereas $\mathrm{Sr}$ desorption is best described by dissolution of $\mathrm{Sr}$-substituted, neo-formed minerals. While, $p \mathrm{CO}_{2}$ had no effect on $\mathrm{Sr}$ or Cs sorption, sediments weathered at $<10$ ppmv $p \mathrm{CO}_{2}$ did desorb more $\mathrm{Sr}(66 \%$ vs. $28 \%)$ and $\mathrm{Cs}(13 \%$ vs. $8 \%)$ during leaching than those weathered at $385 \mathrm{ppmv} p \mathrm{CO}_{2}$. Thus, the dissolution of neo-formed aluminosilicates may represent a long-term, low-level supply of ${ }^{90} \mathrm{Sr}$ at the Hanford site.

\section{INTRODUCTION}

Considerable efforts have been made toward understanding the behavior of contaminants introduced into sediments surrounding high-level radioactive waste (HLRW) storage sites at several Department of Energy (DOE) facilities (Hanford Site, WA; Savannah River Site, SC; Oak Ridge Site, TN) (1-12). Principal radionuclide contaminants at the Hanford 
Site- $-{ }^{137} \mathrm{Cs},{ }^{90} \mathrm{Sr}$, and ${ }^{129} \mathrm{I}$ - have markedly different reactive transport behaviors influenced by the chemical composition of the waste solution and its interaction with the solid phase $(6,9,13,14)$. Hyperalkaline, high ionic-strength waste solutions can induce rapid, incongruent sediment weathering reactions that dramatically alter contaminant sequestration $(5,10,15-17)$. Prior laboratory experiments, conducted to mimic wastesediment interaction under 'near-field' conditions (i.e., close proximity to highly alkalinized waste $(18,19))$ indicate that co-precipitation of $\mathrm{Cs}$ and $\mathrm{Sr}$ within de novo feldspathoid and carbonate mineral assemblages can occur due to the combination of hyperalkalinity $(\mathrm{pH}>13.5)$, with elevated $\mathrm{Al}_{(\mathrm{aq})}$ and $\mathrm{NO}_{3(\mathrm{aq})}$ concentrations $(8,12,17,20)$. This geochemical process has been documented in experiments involving homogeneous nucleation, specimen clays, and pristine Hanford sediments $(2,5,8,10-12,16)$. This reduced contaminant mobility is significant given the severity of radioactive contamination at the Hanford site $(15,18)$. However, toward the DOE goal of site closure, the long-term persistence of these co-precipitates must be assessed, especially for conditions where sediment pore water is again fed by rainwater recharge after removal of the caustic source. Thermodynamic calculations predict infiltration solutions may then be under-saturated with respect to the feldspathoid weathering products, thereby promoting dissolution $(16,21)$. The rate of neo-formed feldspathoid dissolution and subsequent contaminant desorption under these conditions remains unknown. Prior studies of Cs and Sr desorption from Hanford sediments have focused on ion exchange processes $(3,6,14)$ and carbonate dissolution (6). Alteration of the sediments during hyperalkaline weathering certainly may have effects on ion exchange processes (22), but perhaps more significant is the potential for subsequent dissolution of neo-formed minerals to re-supply 
contaminants over the long-term. In addition, sediments are likely exposed to a $p \mathrm{CO}_{2}$ gradient between the center and edge of the plume. The $p \mathrm{CO}_{2}$ has obvious effects on $\mathrm{Sr}$ fate through its control of $\mathrm{SrCO}_{3}(\mathrm{~s})$ or $\mathrm{Sr}$-substituted calcite precipitation. More broadly however, $p \mathrm{CO}_{2}$ concentrations modulate the release of $\mathrm{Ca}$ into the evolving porewaters by poising native calcite weathering rates. Elevated Ca could shift the trajectory of neomineral formation toward cementitious end-products rather than the feldspathoid/zeolite phases most commonly studied (20). Thus, our goal was to evaluate the long-term desorption of Cs, Sr, and I from Hanford sediments weathered in the presence and absence of gas phase $\mathrm{CO}_{2}$ and trace levels of $\mathrm{Cs}$, Sr and I (12). Contaminant desorption was interpreted in the context of a reactive transport model and on the basis of solid phase characterizations. Our results suggest dissolution of neo-formed minerals dominates Sr desorption, while Cs desorption can be explained by ion-exchange processes alone. In addition, both contaminants exhibited greater desorption from sediments weathered under low $p \mathrm{CO}_{2}$.

\section{MATERIALS AND METHODS}

Sample Collection. Sediments similar in character to those beneath the leaking underground tanks at the DOE Hanford Site were collected from uncontaminated areas within the Hanford Formation. Sediments were collected from the 218-E-12B Burial Ground excavation site (23). Sediments were air dried, sieved to obtain the $<2 \mathrm{~mm}$ fraction, and used without further modification. 
Sediment contamination/reaction procedure. We modified and upscaled the

experimental batch reactions used by Chorover and co-workers $(11,12,20,24)$ known to promote rapid, incongruent silicate weathering and feldspathoid formation. This method was chosen in order to produce a large mass of homogeneously reacted material for use in multiple experiments, one of which is presented in this paper.

Acid washed polypropylene co-polymer (PPCO) vessels were used instead of glassware at all stages of the experiment to prevent Si contamination. Sediments were reacted using $20 \mathrm{~L}$ PPCO carboys containing $400 \mathrm{~g}$ of air dry sediment with $20 \mathrm{~kg}$ of synthetic tank waste leachate (STWL) (solid-to-solution mass ratio of 1:50) prepared by mixing STWL stock (described below) and individual contaminant stock solutions $(0.1 \mathrm{~m}$ $\mathrm{Sr}^{2+}, \mathrm{Cs}^{+}$, and $\mathrm{I}^{-}$) together with $\sim 12.8 \mathrm{~kg} \mathrm{H}_{2} \mathrm{O}$. Stock solutions were prepared using $1.8 \mathrm{x}$ $10^{5} \Omega$-m water (Barnstead nanopure) and reagent grade $\mathrm{NaNO}_{3}, \mathrm{NaOH}, \mathrm{CsCl}$, $\mathrm{SrCl}_{2} \cdot 6 \mathrm{H}_{2} \mathrm{O}$ (J.T. Baker) and $\mathrm{NaAlO}_{2} \cdot \mathrm{xH}_{2} \mathrm{O}$ powder (EM Science) as obtained from the manufacturer, to reach final solution concentrations of $0.05 m \mathrm{NaAlO}_{2}, 2.0 \mathrm{~m} \mathrm{Na} \mathrm{Na}^{+}, 1.0 \mathrm{~m}$ $\mathrm{NO}_{3}$ and $1.0 m \mathrm{OH}^{-}(\mathrm{pH} \sim 13.7)$. STWL stocks were prepared by adding $\mathrm{NaAlO}_{2} \cdot \mathrm{xH}_{2} \mathrm{O}$ powder to $15 \mathrm{~m} \mathrm{NaOH}$, stirring for $>1 \mathrm{~h}$ and then adding $0.45 \mu \mathrm{m}$ vacuum-filtered $6 \mathrm{~m}$ $\mathrm{NaNO}_{3}$. The entire mixture was then stirred for $>1 \mathrm{~h}$ and vacuum-filtered again. All STWL solutions were prepared in a $\mathrm{CO}_{2}$-free glovebox (10 ppmv $p \mathrm{CO}_{2}$ detection limit: $\mathrm{CO}_{2}$ sensor model \#GMW21D, Vaisala Group, Finland) by circulating glove box air through four $4 \mathrm{~m} \mathrm{NaOH}$ traps set in series. $\mathrm{CsCl}, \mathrm{SrCl}_{2} \cdot 6 \mathrm{H}_{2} \mathrm{O}$, and $\mathrm{NaI}$ were added to the STWL stock solution as "co-contaminants" to give $10^{-5} m\left(\mathrm{Cs}^{+}\right.$and $\left.\mathrm{Sr}^{2+}\right)$ and $10^{-7} \mathrm{~m}\left(\mathrm{I}^{-}\right)$. Sediment reaction carboys were reacted for 182 days in either (1) $\mathrm{CO}_{2}$-free conditions (" $\left[-\mathrm{CO}_{2}\right]$ ", undetectable at $<10 \mathrm{ppmv}$ ) within the above mentioned glovebox or 
(2) atmospheric $\mathrm{CO}_{2}$ conditions (" $\left[+\mathrm{CO}_{2}\right]$ ", 386 ppmv, maintained by flushing the carboy headspace with water-saturated air). The carboys were manually shaken once-per-day for five out of every seven days. The reacted sediment was collected and separated from the solution by centrifugation at $27,257 \mathrm{~g}$ for $45 \mathrm{~min}$. The sediment was washed three times with $95 \%$ ethanol followed by a final wash with $1.8 \times 10^{5} \Omega-\mathrm{m}$ water. The reacted sediment was then freeze-dried, homogenized and stored at $25^{\circ} \mathrm{C}$.

Sediment Characterization. Reacted and unreacted sediment was characterized by selective chemical extractions, total elemental analysis, FTIR and quantitative-XRD. Selective chemical extractions included: (a) $\mathrm{Mg}\left(\mathrm{NO}_{3}\right)_{2}$ - acid ammonium oxalate (AAO) sequential extraction protocol discussed in Choi et al., (11) and (b) a $5 \mathrm{~h}$ extraction with 1.0 $\mathrm{M}$ ammonium-acetate $\left(\mathrm{NH}_{4} \mathrm{OAc}\right)$ adjusted to $\mathrm{pH} 5$ (25) performed in the dark on a horizontal shaker. $\mathrm{Mg}\left(\mathrm{NO}_{3}\right)_{2}, \mathrm{AAO}$, and $\mathrm{NH}_{4} \mathrm{OAc}$ extractions target exchangeable cations, short-range-ordered minerals, and carbonates, respectively. Total element concentrations were measured following Li-metaborate fusion (26), total inorganic carbon was analyzed by phosphoric acid addition in a Shimadzu 5000A-SSM TOC analyzer (Columbia, MD). Metal(loid)s were analyzed using ICP-MS (Perkin Elmer DRC II, Waltham, MA). Total nitrogen was measured following the procedure of Schroeder et al (27). Cation exchange capacity (CEC) was measured using a modified Cohex method (28) carried out by measuring the decrease in aqueous Cohex after shaking $2 \mathrm{~g}$ of sediment for $2 \mathrm{~h}$ with $25 \mathrm{ml}$ of $0.4 \mathrm{cmol} \mathrm{l}^{-1}$ Cohex. DRIFT-FTIR spectroscopy was accomplished on a Nicolet Magna 560 FTIR spectrometer (Thermo Sci., Waltham, MA) after gently grinding $9 \mathrm{mg}$ of freeze-dried sediment (previously ground to dryness three 
times in acetone) with $441 \mathrm{mg}$ of ground analytical grade $\mathrm{KBr}$ crystals. Representative samples were examined by transmission electron microscopy (TEM) with a Hitachi $\mathrm{H} 8100 \mathrm{LaB}_{6}$ TEM operating at $200 \mathrm{kV}$ coupled with energy-dispersive X-ray spectrometry (EDS). X-ray diffraction (XRD) was conducted on bulk sediments and a fine particle separate (clay plus silt, $\mathrm{C}+\mathrm{S}$ ) obtained by sonicating the sediments in ethanol for 8 min., sampling the suspension after 2 min. of settling time, and oven-drying the samples at $60^{\circ} \mathrm{C}$ for $6 \mathrm{~h}$. XRD data were collected at the Stanford Synchrotron Radiation Laboratory on beamline 11-3 (focused, $12735 \mathrm{eV}$ ) in transmission mode. QuantitativeXRD phase analysis was performed using the Rietveld module in the X'Pert HighScore Plus software.

Column experiments. Reacted sediments were subjected to continuous leaching at a uniform flow rate $\left(\sim 0.04 \mathrm{ml} \mathrm{min}^{-1}\right)$ for $8 \mathrm{~d}$ corresponding to between $500-600$ pore volumes (PVs) depending on small differences in the flow rate and pore volumes (nominal $0.7 \mathrm{~cm}^{3}$ ) between treatments. Triplicate columns for each treatment were prepared similarly by dry packing $\sim 1.8 \mathrm{~g}$ of washed, freeze-dried sediment into $9.13 \times 10^{-}$ ${ }^{3} \mathrm{~m}$ I.D. X $2.1 \times 10^{-2} \mathrm{~m}$ long (pack length) columns, yielding an average porosity of 0.52 . Hanford background pore water (BPW) solution was prepared by adding (all reagent grade) $210.4 \mathrm{mg} \mathrm{NaCl}, 8.4 \mathrm{mg} \mathrm{NaHCO}_{3}, 22.4 \mathrm{mg} \mathrm{KCl}, 292.7 \mathrm{mg} \mathrm{CaSO}_{4} \cdot 2 \mathrm{H}_{2} \mathrm{O}, 147.0 \mathrm{mg}$ $\mathrm{CaCl}_{2} \cdot 2 \mathrm{H}_{2} \mathrm{O}, 203.3 \mathrm{mg} \mathrm{MgCl}_{2} \bullet 6 \mathrm{H}_{2} \mathrm{O}$ to a 1-L PPCO bottle, shaking the mixture for 30 min., bubbling air via a PPCO pipette for $2-12 \mathrm{~h}$ and then adjusting the $\mathrm{pH}$ to 7.2 with $\mathrm{NaOH}$ until the $\mathrm{pH}$ was stable. The final solution molalities were: $3.6 \times 10^{-3} \mathrm{~m} \mathrm{NaCl}, 0.1$ x $10^{-3} m \mathrm{NaHCO}_{3}, 0.3 \times 10^{-3} \mathrm{~m} \mathrm{KCl}, 1.7 \times 10^{-3} \mathrm{~m} \mathrm{CaSO}_{4}, 1.0 \times 10^{-3} \mathrm{~m} \mathrm{CaCl}_{2}, 1.0 \times 10^{-3} \mathrm{~m}$ $\mathrm{MgCl}_{2}$, $\mathrm{pH}$ 7.2. This solution was delivered to the columns via Teflon and polyvinyl 
chloride tubing. Effluent was collected in $24 \mathrm{~h}$ increments ( 80 PV's) into parafilmsealed PPCO bottles. Immediately after collection the sample was capped, frozen and stored at $-20^{\circ} \mathrm{C}$ until analysis. A separate set of columns was run specifically for realtime, in-line $\mathrm{pH}$ measurement (VWR gel-filled electrodes) to avoid sample contamination from the $\mathrm{KCl}$ electrode filling solution. Electrode calibrations were checked periodically and found to be within $0.05 \mathrm{pH}$ units throughout the $8 \mathrm{~d}$ experiment. Further details of the column preparation are given in S-1 of the Supporting Information.

Column Experiment Analysis. Effluent samples were thawed in capped bottles, shaken thoroughly before opening, and sampled first for TIC measurement. Although less than ideal, this procedure minimized the potential for loss of TIC due to $\mathrm{CO}_{2}$ exsolvation during freezing while avoiding additional sample splits. Next, a measurement of $\mathrm{pH}$ (Orion Ross $\mathrm{pH}$ electrode) was made to assess the degree of $\mathrm{CO}_{2}(\mathrm{~g})$ acidification during sample collection. Samples were then diluted for analysis of $\mathrm{NO}_{3}$ via ion chromatography (Dionex, Sunnyvale, CA) and metal(loid)s via ICP-MS.

Notation and terms. All concentrations are reported in molal units. All representations of measurement error are presented as one standard deviation of the mean with $n=3$ unless otherwise noted. The term sorption is defined here to include all adsorption and co-precipitation processes resulting in removal from aqueous solution to the solid phase (29); likewise our use of the term desorption indicates the inverse without implying a specific mechanism.

Kinetic dissolution/precipitation modeling. Distribution of species calculations and the simulation of dissolution/precipitation and transport in the column experiments were 
carried out with the reactive transport code Crunchflow (www.csteefel.com). The initial PV's of element desorption were extremely complex involving dissolution of multiple, highly-labile minerals concurrently with evolving ion exchange processes. Preliminary modeling using separate Sr and Cs affinity parameter sets confirms we can neglect transient ion exchange dynamics for $\mathrm{Sr}^{2+}$ at >500 PV's, which adheres primarily to generalized planar sites (6), but we cannot neglect the exchange of $\mathrm{Cs}^{+}$over this period (14). The strong affinity of $\mathrm{Cs}^{+}$for frayed-edge sites (FES) on these illitic sediments extends Cs desorption by ion exchange beyond 300 PV's under our experimental conditions. We therefore set out to couple the 3-site ion exchange model of Steefel et al (14), which was parameterized for Cs exchange on similar Hanford sediments, with a set of mineral dissolution components selected based on XRD and TEM characterization of the reacted materials. Representative mineral reactions include: (A) dissolution of a Srsubstituted feldspathoid $\left[\mathrm{Na}_{(8-2 \mathrm{x})} \mathrm{Sr}_{\mathrm{x}}\left(\left(\mathrm{NO}_{3}\right)_{2} \mathrm{Al}_{6} \mathrm{Si}_{6} \mathrm{O}_{24}\right)\right.$, where $\mathrm{x}$ is the Sr stoichiometry]; (B) precipitation of an aluminosilicate $\left[\mathrm{Si}_{2} \mathrm{Al}_{2} \mathrm{O}_{5}(\mathrm{OH})_{4}\right]$ and gibbsite $\left[\mathrm{Al}(\mathrm{OH})_{3}\right]$ to balance excess $\mathrm{Al}$ and $\mathrm{Si}$; (C) exploration of calcite $\left[\mathrm{CaCO}_{3}\right]$ precipitation/dissolution to provide $\mathrm{pH}$ buffering. Due to the lack of knowledge of specific surface area and abundance of feldspathoid in the reacted sediment, we present feldspathoid dissolution rates in $\mathrm{mol}_{\text {mineral }} \mathrm{m}^{-3}$ sediment $\mathrm{s}^{-1}$ rather than on the typical specific surface area basis. Log K values (S-2 of the Supporting Information) for the minerals were obtained from the EQ3 database for gibbsite, kaolinite, calcite and strontianite (30); and from Deng et al (16) for the feldspathoid (sodalite).

\section{RESULTS}


Reactive Sediment Weathering. In both treatments, 6 mo. of reaction with STWL caused an increase in solid phase $\mathrm{Sr}, \mathrm{Cs}$, I and Al concentrations (loss from STWL solution), and a partial repartitioning of $\mathrm{Fe}$ and $\mathrm{Si}$ to $\mathrm{AAO}$ and $\mathrm{NH}_{4} \mathrm{OAc}$ extractable pools (Table 1). Approximately $60 \%$ of the STWL Sr and $15 \%$ of the STWL Cs were sorbed to the sediments; I sorption was confirmed in the solid phase but could not be quantified because of instrumental detection limits. The $\left[-\mathrm{CO}_{2}\right]$ treatment exhibited the greatest $\mathrm{Al}$ sorption and the greatest increases in $\mathrm{AAO}$ extractable $\mathrm{Al}, \mathrm{Si}$, and $\mathrm{Fe}$. The $\left[-\mathrm{CO}_{2}\right]$ treatment also exhibited greater Fe repartitioning to $\mathrm{NH}_{4} \mathrm{OAc}$ pools and greater overall iodine sorption than the $\left[+\mathrm{CO}_{2}\right]$ treatment (Table 1). However, $p \mathrm{CO}_{2}$ levels did not affect $\mathrm{Sr}$ and Cs contaminant sorption. Comparing the AAO portion of the sequential $\operatorname{Mg}\left(\mathrm{NO}_{3}\right)_{2}$ - AAO extraction against the $\mathrm{NH}_{4} \mathrm{OAc}$ extraction, the former removed a greater portion of the sediment $\mathrm{Al}, \mathrm{Si}$, and $\mathrm{Fe}$ and the $\mathrm{NH}_{4} \mathrm{OAc}$ extraction removed slightly more $\mathrm{Cs}$ and considerably more $\mathrm{Ca}$ and $\mathrm{Sr}$. $\mathrm{Ca}$ - and $\mathrm{Sr}$-oxalate precipitation during the AAO extraction may be one explanation, as the extracting solution was oversaturated with respect to both solids $\left(\mathrm{K}_{\mathrm{so}}\right.$ values from $\left.(31)\right)$. However, in prior extractions of similar sediments, $\mathrm{Sr}$ oxalate was not detected via Sr-XAFS (10). Total inorganic carbon (TIC) concentrations $\left(150 \pm 2_{\text {(s.d) }} \mathrm{mmol} \mathrm{kg}^{-1}\right.$ for the native sediment) decreased in the $\left[-\mathrm{CO}_{2}\right]$ treatment to $54 \pm$ $3_{(\mathrm{s} . \mathrm{d})} \mathrm{mmol} \mathrm{kg}^{-1}$ and increased in the $\left[+\mathrm{CO}_{2}\right]$ treatment to $190 \pm 5_{(\mathrm{s.d})} \mathrm{mmol} \mathrm{kg}^{-1}$. Interestingly, this trend reversed during sediment leaching with BPW; TIC increased to $62 \pm 1_{(\mathrm{s} . \mathrm{d})} \mathrm{mmol} \mathrm{kg}^{-1}$ in the $\left[-\mathrm{CO}_{2}\right]$ treatment and decreased to $151 \pm 2_{(\mathrm{s.d})} \mathrm{mmol} \mathrm{kg}^{-1}$ in $\left[+\mathrm{CO}_{2}\right]$ treatment. Total nitrogen was below detection $\left(<7 \mathrm{mmol} \mathrm{kg}^{-1}\right)$ in the native sediment, increased after weathering to $64 \pm 3_{(\text {s.d) }}$ and $62 \pm 3_{(\text {s.d) }} \mathrm{mmol} \mathrm{kg}^{-1}$ for the $\left[-\mathrm{CO}_{2}\right]$ and $\left[+\mathrm{CO}_{2}\right]$ treatments, respectively and then decreased after leaching to $53 \pm 3_{(\mathrm{s.d})}$ and 55 
$\pm 3_{(\mathrm{s.d})} \mathrm{mmol} \mathrm{kg}^{-1}$ for the $\left[-\mathrm{CO}_{2}\right]$ and $\left[+\mathrm{CO}_{2}\right]$ treatments, respectively. Sediment CEC values decreased after reactive weathering in both treatments from $87.9 \pm 0.9_{\text {(s.d) }} \mathrm{mmol}_{\mathrm{C}}$ $\mathrm{kg}^{-1}$ for the native sediment, to $58.0 \pm 1.1_{(\mathrm{s.d})}$ and $75.0 \pm 0.9_{(\mathrm{s} . \mathrm{d})} \mathrm{mmol}_{\mathrm{C}} \mathrm{kg}^{-1}$ for the $\left[-\mathrm{CO}_{2}\right]$ and $\left[+\mathrm{CO}_{2}\right]$ treatments, respectively.

Quantitative XRD (qXRD) suggests the unreacted sediment is dominated by quartz (38\%), plagioclase (36\%) and micas (22\%) with an enrichment of illite, vermiculite and chlorite in fine particle separates (S-3 of the Supporting Information). After reaction with STWL, qXRD indicates most of the chlorite and vermiculite and a portion of the quartz, plagioclase and illite have dissolved, whereas relative increases are observed for muscovite and hornblende. Neo-precipitation of the feldspathoids sodalite and cancrinite represent $23 \%$ and $24 \%$ of the fine particle separate (an estimated $6 \%$ of the bulk sediment) in the $\left[+\mathrm{CO}_{2}\right]$ and $\left[-\mathrm{CO}_{2}\right]$ treatments, respectively. A neo-precipitate strätlingite $\left[\mathrm{Ca}_{2} \mathrm{Al}_{2} \mathrm{SiO}_{7} \cdot 8\left(\mathrm{H}_{2} \mathrm{O}\right)\right]$ was observed in the $\left[-\mathrm{CO}_{2}\right]$ treatment. Upon reaction, the sediments also took on a reddish hue and we noted Fe enrichments on the surfaces of neo-precipitates in our TEM/EDX analysis, but we did not observe any crystalline Fe(oxyhydr)oxides by XRD. We attribute this to neo-precipitation of short-range-ordered Fe (oxyhydr)oxides (e.g., 32).

Sediment leaching. After $500 \mathrm{PV}$, effluent $\mathrm{pH}$, and contaminant and major cation concentrations reached an apparent pseudo steady-state condition between ion exchange reactions and slower dissolution/precipitation reactions (Figure 1). At this point, $\mathrm{I}^{-}$ concentrations were equivalent to those in the feed solution (not shown), indicating most of the labile $\mathrm{I}^{-}$pool had already desorbed from the sediments. The $p \mathrm{CO}_{2}$ concentration during weathering had no effect on the long-term desorption effluent concentrations of 
Sr, but effluent $\mathrm{Cs}$ was lower in the $\left[+\mathrm{CO}_{2}\right]$ compared with the $\left[-\mathrm{CO}_{2}\right]$ treatment (Figure 1). Minimizing $p \mathrm{CO}_{2}$ during weathering thus resulted in a greater proportion of $\mathrm{Sr}$ and $\mathrm{Cs}$ being removed during the leaching experiment (Figure 2). For $\mathrm{Sr}$ in particular, much of this greater removal in the $\left[-\mathrm{CO}_{2}\right]$ treatment occurred during early PVs (Figure 2). After $500 \mathrm{PV},\left[-\mathrm{CO}_{2}\right]$ sediments produced effluent $\mathrm{pH}$ values (measured on-line to avoid $\mathrm{CO}_{2}$ absorption) of 9.0, ca. $0.2 \mathrm{pH}$ units above those exposed to $\mathrm{CO}_{2}$ during sorption. However, effluent inorganic carbon showed no long-term treatment effect (S-4 of the Supporting Information). There were only minor qualitative changes in the XRD diffractorgrams after $\sim 600$ PV of leaching, however Rietveld fitting reveals a decrease of $4 \%$ and $2 \%$ in the feldspathoid content for the $\left[+\mathrm{CO}_{2}\right]$ and $\left[-\mathrm{CO}_{2}\right]$ treatments, respectively, a $2 \%$ decrease in strätlingite content in the $\left[-\mathrm{CO}_{2}\right]$ treatment, and minor kaolinite increases (Figure S-3 of the Supporting Information).

Reactive Transport Modeling. The influent BPW solution is strongly undersaturated with respect to the neo-formed feldspathoids and strätlingite (10). Conversely, both treatment effluents are slightly oversaturated with respect to gibbsite and kaolinite and undersaturated with respect to calcite and strontianite (S-2 of the Supporting Information).

Using the exchange affinity dataset of Steefel et al (14), Cs efflux between 300 and 600 PV's can be explained solely by ion exchange reactions on FES. This follows from the extremely high affinity of Cs for the $\operatorname{FES}(3,14)$. The principal cation exchanging for $\mathrm{Cs}^{+}$is $\mathrm{K}^{+}{ }_{(\mathrm{aq})}$. When the $\mathrm{K}-\mathrm{Na}$ selectivity coefficient in the Steefel et al 
parameter set (14) is adjusted to match the K sorption curve, the Cs desorption breakthrough aligns with the measured data (Figure 3).

Strontium desorption behavior after 500 PV's is well approximated by dissolution of neoformed feldspathoids substituted with $\mathrm{Sr}$ at the stoichiometric ratios of 0.012 and 0.010 for $\left[-\mathrm{CO}_{2}\right]$ and $\left[+\mathrm{CO}_{2}\right]$, respectively (see methods for unit formula). When constrained by $\mathrm{NO}_{3}$ effluent concentrations, feldspathoid dissolution rates were found to be $10^{-3.34}$ and $10^{-3.26} \mathrm{~mol} \mathrm{~m}^{-3}$ sediment $\mathrm{s}^{-1}$ for $\left[-\mathrm{CO}_{2}\right]$ and $\left[+\mathrm{CO}_{2}\right]$, respectively. For $600 \mathrm{PV}$ 's of leaching this corresponds to an estimate $8 \%$ loss of feldspathoid mass, which is of the same order of magnitude as the $3 \%$ loss observed via XRD (S-3 of the Supporting Information). The modeled effluent $\mathrm{Al}$ and $\mathrm{Si}$ concentrations from feldspathoid dissolution were elevated relative to the measured values, so precipitation of an aluminosilicate (approximated by kaolinite with specific surface area (SSA) $=11.4 \mathrm{~m}^{2} \mathrm{~g}^{-}$ ${ }^{1}$ ) and an aluminum hydroxide (approximated by gibbsite with SSA $=2.0 \mathrm{~m}^{2} \mathrm{~g}^{-1}$ ) was included to match the effluent $\mathrm{Si}$ and $\mathrm{Al}$ concentrations. The required precipitation rates in $\log$ form $\left(\mathrm{mol} \mathrm{m}^{-2}\right.$ mineral $\left.\mathrm{s}^{-1}\right)$ were -8.5 and -8.3 for the aluminum hydroxide in the [$\left.\mathrm{CO}_{2}\right]$ and $\left[+\mathrm{CO}_{2}\right]$, respectively, and -11.0 and -10.5 for the aluminosilicate in the $\left[-\mathrm{CO}_{2}\right]$ and $\left[+\mathrm{CO}_{2}\right]$, respectively. This provided a unique fit to the data.

\section{DISCUSSION}

The qXRD, FTIR, TEM-EDS, and selective extraction data all confirm the formation of feldspathoid minerals in our reacted sediments consistent with prior observations $(2,10$, 12, 24)(see Table 1 and S-3, S-5 and S-6 of the Supporting Information). 
Influence of $\boldsymbol{p} \mathbf{C O}_{2}$. The $p \mathrm{CO}_{2}$ during STWL reaction did not alter the total $\mathrm{Sr}$ and $\mathrm{Cs}$ sorption (Table 1), but it did impact mineral weathering processes ( $\mathrm{S}-3$ of the Supporting Information) and the subsequent desorption during BPW leaching. More Sr (66\% vs. $28 \%)$ and Cs (13\% vs. 8\%) was desorbed in BPW from sediments weathered in the absence of $\mathrm{CO}_{2}$ (Figure 2). For Sr, the greatest desorption rates were measured at early PV's. This Sr was likely sorbed to ion exchange sites or kinetically labile minerals. This is consistent with higher $\mathrm{Mg}\left(\mathrm{NO}_{3}\right)_{2}$ extractable $\mathrm{Sr}$ (but lower $\mathrm{Ca}$ ) measured in the $\left[-\mathrm{CO}_{2}\right]$ treatment (Table 1). Since the total amount of Sr taken up by the $\left[+\mathrm{CO}_{2}\right]$ and $\left[-\mathrm{CO}_{2}\right]$ reacted sediments was similar (Table 1), $p \mathrm{CO}_{2}$ appears to affect the partitioning of contaminant Sr sorption into solid phase species, which in turn controls its subsequent susceptibility to desorption in BPW. The dissolution of native calcite and neo-formation of strätlingite - which can incorporate $\mathrm{Sr}$ - in the $\left[-\mathrm{CO}_{2}\right]$ treatment may play an important role in the early PV release of Sr.

Effects of $p \mathrm{CO}_{2}$ on $\mathrm{Cs}$ desorption were more subtle (despite greater Cs desorption from the $\left[-\mathrm{CO}_{2}\right]$ than the $\left[+\mathrm{CO}_{2}\right]$ case) and not as clearly related to species partitioning during sorption. Given the low concentrations of Cs in the STWL and low mass of Cs sorbed to the sediment $\left(\sim 0.1 \mathrm{mmol} \mathrm{kg}{ }^{-1}\right.$, see Table 1$)$, we can assume nearly all Cs was initially adsorbed to high affinity frayed edge sites, which are expected to have concentrations as large as $2 \mathrm{mmol}_{\mathrm{c}} \mathrm{kg}^{-1}$ in these sediments $(3,14)$ (Table 1 , note FESbound $\mathrm{Cs}^{+}$is not likely extracted by $\left.\mathrm{Mg}\left(\mathrm{NO}_{3}\right)_{2}\right)$. In our BPW leaching experiments, we expect $\mathrm{Cs}^{+}$desorption from high affinity sites is strongly controlled by influent $\mathrm{K}^{+}$ concentrations. Our modeling shows equilibrium $\mathrm{K}^{+}$filling of the planar sites precedes any significant displacement of FES-bound $\mathrm{Cs}^{+}$. Since the CEC decreased much more for 
the $\left[-\mathrm{CO}_{2}\right]$ treatment than for the $\left[+\mathrm{CO}_{2}\right]$ treatment during STWL weathering, influent $\mathrm{K}^{+}$ should fill the planar sites in the $\left[-\mathrm{CO}_{2}\right]$ treatment at an earlier PV than the $\left[+\mathrm{CO}_{2}\right]$ treatment. Subsequently, this should initiate $\mathrm{K}^{+}$competition with FES-sorbed $\mathrm{Cs}^{+}$at an earlier PV, resulting in earlier $\mathrm{Cs}^{+}$desorption in the $\left[-\mathrm{CO}_{2}\right]$ than the $\left[+\mathrm{CO}_{2}\right]$ treatment (see Figures 1, 2 and 3). This proposed mechanism is consistent with greater overall weathering in the $\left[-\mathrm{CO}_{2}\right]$ treatment.

It is important to note however, that $p \mathrm{CO}_{2}$ has only a minor impact on the longterm $\mathrm{Cs}$ and $\mathrm{Sr}$ desorption rates or effluent concentrations (Figure 1). In fact, although long-term differences do exist between treatments, long-term fractional desorption rates $(>500 \mathrm{PV})$ for both contaminants in both treatments fall within a narrow range of $0.0001-0.0004 f_{\mathrm{m}} \mathrm{PV}^{-1}$ (S-7 of the Supporting Information), where $f_{\mathrm{m}}$ is the fraction of total contaminant sorbed to the sediment. This bodes well for future modeling efforts because it suggests long-term re-supply of $\mathrm{Sr}$ and Cs should be less subject to nonlinear effects due to initial $p \mathrm{CO}_{2}$.

Modeled Cs desorption characteristics. Although the shape of the Cs desorption curve after $500 \mathrm{PV}$ s suggests steady state mineral dissolution, we can fit it by adjusting the initial Cs loading on the exchange sites to 0.032 and $0.029 \mathrm{mmol}_{\mathrm{c}} \mathrm{kg}^{-1}$ for $\left[-\mathrm{CO}_{2}\right]$ and $\left[+\mathrm{CO}_{2}\right]$, respectively. At these loadings, our model predicts $\mathrm{Cs}$ to partition almost entirely to the FES where Cs desorption is governed primarily by $\mathrm{K}^{+}$exchange (Figure 3). This does not prove that Cs is excluded from co-precipitating with neoformed minerals during the weathering process, but rather that there is no need to invoke mineral dissolution to explain the dataset. In fact, the mass of Cs sorbed by the sediments $\left(\sim 0.1 \mathrm{mmol} \mathrm{kg}^{-1}\right)$ is 
well below the expected FES density (ca. $\left.2 \mathrm{mmol}_{\mathrm{c}} \mathrm{kg}^{-1}\right)(3,14)$. Nonetheless, after 600 PVs only $16 \%$ of the applied Cs has been desorbed.

Modeled Sr desorption characteristics. The effluent data and the modeling are both consistent with our hypothesis that neoformed mineral dissolution controls Sr desorption at $>500 \mathrm{PV}$. The model can accommodate all of the Sr within the dissolving feldspathoid, with the dissolution rate constrained by $\mathrm{NO}_{3}$ effluent concentrations (Figure 1). TEMEDS spectra provide evidence for $\mathrm{Sr}$ association with the feldspathoids, whereas decreases in: (1) total solid phase $\mathrm{N}$; (2) the intensity of $\mathrm{NO}_{3}$-stretching vibrations (1379 and $1419 \mathrm{~cm}^{-1}$ ) in FTIR spectra; and (3) the qXRD feldspathoid content are all consistent with dissolution of this phase during leaching (S-3 of the Supporting Information). If we assume congruent feldspathoid dissolution, modeled effluent $\mathrm{Al}$ and $\mathrm{Si}$ concentrations are higher than those measured. Stopped-flow experiments conducted at the end of the leaching period indicate both $\mathrm{Al}$ and Si-bearing solids are precipitating (data not shown). Thus, incongruent dissolution of feldspathoid minerals, coupled to aluminosilicate and/or aluminum hydroxide precipitation, as modeled, is likely. Clearly, other mineral dissolution and precipitation reactions co-occur during the leaching process, which may or may not have direct bearing on Cs and Sr desorption characteristics, but certainly impact other effluent component concentrations. A good example is the potential for carbonate minerals (e.g, calcite and strätlingite) to influence effluent $\mathrm{Ca}^{2+}, \mathrm{Sr}^{2+}$ and $\mathrm{H}^{+}$ activities. Additionally, Fe neo-precipitates may play a role in the early (low PV) desorption of contaminants (e.g., 32) or as mobile colloid carriers.

This study illustrates the need to incorporate mineral dissolution into conceptual and numerical models of (at least) Sr desorption under future Hanford site closure 
scenarios. Dissolution of co-precipitates (i.e., feldspathoids) formed during the reaction of liquid waste with siliceous sediments can serve as a long-term source of Sr desorption. Because these dissolution processes are likely active during all stages of sediment leaching, future modeling efforts should include a mineral dissolution component even when shorter-term ion exchange processes dominate. This work also suggests that ion exchange remains a dominant process governing Cs dynamics even after considerable leaching.

\section{SUPPORTING INFORMATION AVAILABLE}

(S-1) Description of column preparation, parameter table and tracer breakthrough. (S-2) Table of mineral saturation indicies (SI) for the effluent. (S-3) Quantitative XRD spectra and Table. (S-4) Figure of effluent $\mathrm{Ca}$ and TIC. (S-5) FTIR spectra of the reacted sediment. (S-6) TEM micrograph and EDS spectrum of feldspathoids. (S-7) Fractional Cs and Sr desorption. (S-8) Effluent speciation data. This material is available free of charge via the Internet at http://pubs.acs.org.

\section{ACKNOWLEDGEMENTS}

We thank R. Jeff Serne for his invaluable assistance in selection of suitable sediment material. We thank Mary Kay Amistadi for ICP-MS analysis and Philip Anderson for TEM support. Comments from three anonymous reviewers greatly improved the quality of this manuscript. This work was supported by the U.S. Department of Energy, Office of Science, Office of Biological and Environmental 
Research (Subsurface Environmental System-Sciences Program) under Grant No. DEFG02-06ER64190, and Contract No. DE-AC02-05CH11231.

\section{REFERENCES}

(1) McKinley, J. P.; Zeissler, C. J.; Zachara, J. M.; Serne, R. J.; Lindstrom, R. M.; Schaef, H. T.; Orr, R. D., Distribution and retention of Cs-137 in sediments at the Hanford Site, Washington. Environ. Sci. Technol. 2001, 35, 3433-3441.

(2) Deng, Y.; Harsh, J. B.; Flury, M.; Young, J. S.; Boyle, J. S., Mineral formation during simulated leaks of Hanford waste tanks. Appl. Geochem. 2006, 21, 1392 - 1409.

(3) Zachara, J. M.; Smith, S. C.; Liu, C. X.; McKinley, J. P.; Serne, R. J.; Gassman, P. L., Sorption of $\mathrm{Cs}^{+}$to micaceous subsurface sediments from the Hanford site, USA. Geochim. Cosmochim. Acta 2002, 66, 193-211.

(4) Bickmore, B. R.; Nagy, K. L.; Young, J. S.; Drexler, J. W., Nitrate-cancrinite precipitation on quartz sand in simulated Hanford tank solutions. Environ. Sci. Technol. 2001, 35, 4481-4486.

(5) Zhao, H. T.; Deng, Y. J.; Harsh, J. B.; Flury, M.; Boyle, J. S., Alteration of kaolinite to cancrinite and sodalite by simulated Hanford tank waste and its impact on cesium retention. Clay Clay Miner. 2004, 52, 1-13.

(6) McKinley, J. P.; Zachara, J. M.; Smith, S. C.; Liu, C., Cation exchange reactions controlling desorption of ${ }^{90} \mathrm{Sr}^{2+}$ from coarse-grained contaminated sediments at the Hanford site, Washington. Geochim. Cosmochim. Acta 2007, 71, 305-325.

(7) Conrad, M. E.; DePaolo, D. J.; Maher, K.; Gee, G. W.; Ward, A. L., Field evidence for strong chemical separation of contaminants in the Hanford vadose zone. Vadose Zone Journal 2007, 6, 1031-1041.

(8) Mashal, K.; Harsh, J. B.; Flury, M., Clay mineralogical transformations over time in Hanford sediments reacted with simulated tank waste. Soil Sci. Soc. Am. J. 2005, 69, 531538.

(9) Ainsworth, C. C.; Zachara, J. M.; Wagnon, K.; McKinley, S.; Liu, C.; Smith, S. C.; Schaef, H. T.; Gassman, P. L., Impact of highly basic solutions on sorption of $\mathrm{Cs}^{+}$to subsurface sediments from the Hanford site, USA. Geochim. Cosmochim. Acta 2005, 69, 4787-4800.

(10) Chorover, J.; Choi, S.; Rotenberg, P.; Serne, R. J.; Rivera, N.; Strepka, C.; Thompson, A.; Mueller, K. T.; O'Day, P. A., Silicon control of strontium and cesium partitioning in hydroxide-weathered sediments. Geochim. Cosmochim. Acta 2008, 72, 2024-2047.

(11) Choi, S.; Amistadi, M. K.; Chorover, J., Clay mineral weathering and contaminant dynamics in a caustic aqueous system: I. Wet chemistry and aging effects. Geochim. Cosmochim. Acta 2005, 69, 4425-4436.

(12) Chorover, J.; Choi, S. K.; Amistadi, M. K.; Karthikeyan, K. G.; Crosson, G.; Mueller, K. T., Linking cesium and strontium uptake to kaolinite weathering in simulated tank waste leachate. Environ. Sci. Technol. 2003, 37, 2200-2208. 
(13) Um, W.; Serne, R. J.; Krupka, K. M., Linearity and reversibility of iodide adsorption on sediments from Hanford, Washington under water saturated conditions. Water Res. 2004, 38, 2009-2016.

(14) Steefel, C. I.; Carroll, S.; Zhao, P. H.; Roberts, S., Cesium migration in Hanford sediment: a multisite cation exchange model based on laboratory transport experiments. J. Contam. Hydrol. 2003, 67, 219-246.

(15) Zachara, J. M.; Serne, J.; Freshley, M.; Mann, F.; Anderson, F.; Wood, M.; Jones, T.; Myers, D., Geochemical processes controlling migration of tank wastes in Hanford's vadose zone. Vadose Zone Journal 2007, 6, 985-1003.

(16) Deng, Y.; Flury, M.; Harsh, J. B.; Felmy, A. R.; Qafoku, O., Cancrinite and sodalite formation in the presence of cesium, potassium, magnesium, calcium and strontium in Hanford tank waste simulants. Appl. Geochem. 2006, 21, 2049-2063.

(17) Um, W.; Serne, R. J.; Yabusaki, S. B.; Owen, A. T., Enhanced radionuclide immobilization and flow path modifications by dissolution and secondary precipitates. $J$. Environ. Qual. 2005, 34, 1404-1414.

(18) Wan, J. M.; Tokunaga, T. K.; Larsen, J. T.; Serne, R. J., Geochemical evolution of highly alkaline and saline tank waste plumes during seepage through vadose zone sediments. Geochim. Cosmochim. Acta 2004, 68, 491-502.

(19) Serne, R. J.; Zachara, J.; Burke, D., Chemical information on tank supernatants, Cs adsorption from tank liquids onto Hanford sediments and field observations of Cs migration from past tank leaks. Pacific Northwest National Laboratory 1998, PNNL11495.

(20) Choi, S.; O'Day, P. A.; Rivera, N. A.; Mueller, K. T.; Vairavamurthy, M. A.; Seraphin, S.; Chorover, J., Strontium speciation during reaction of kaolinite with simulated tank-waste leachate: Bulk and microfocused EXAFS analysis. Environ. Sci. Technol. 2006, 40, 2608-2614.

(21) La Iglesia, A.; Franco, E.; Pozzuoli, A., Stability Diagrams Of Zeolites .2. Phillipsite And Chabazite From Pyroclastic Rocks In Southern Italy. Neues Jahrb. Mineral.-Abh. 1991, 162, 261-280.

(22) Mon, J.; Deng, Y. J.; Flury, M.; Harsh, J. B., Cesium incorporation and diffusion in cancrinite, sodalite, zeolite, and allophane. Microporous And Mesoporous Materials 2005, 86, 277-286.

(23) Riley, R. G.; Zachara, J. M., Chemical Contaminants on DOE Lands and Selection of Contaminant Mixtures for Subsurfaces Sciences Research. In U.S. Department of Energy, Office of Energy Research: 1992.

(24) Choi, S.; Crosson, G.; Mueller, K. T.; Seraphin, S.; Chorover, J., Clay mineral weathering and contaminant dynamics in a caustic aqueous system: II. Mineral transformation and microscale partitioning. Geochim. Cosmochim. Acta 2005, 69, 4437 4451.

(25) Tessier, A.; Campbell, P. G. C.; Bisson, M., Sequential extraction procedure for the speciation of particulate trace-metals. Anal. Chem. 1979, 51, 844-851.

(26) Hossner, L. R., Dissolution for total elemental analysis. In Methods of Soil Analysis: Part 3-Chemical Methods Sparks, D. L., Ed. Soil Science Society of America: Madison, WI, 1996; pp 49-64. 
(27) Schroeder, P. A.; Ingall, E. D., A method for the determination of nitrogen in clays, with application to the burial diagenesis of shales. Journal Of Sedimentary Research Section A-Sedimentary Petrology And Processes 1994, 64, 694-697.

(28) Ciesielski, H.; Sterckeman, T., Determination of cation exchange capacity and exchangeable cations in soils by means of cobalt hexamine trichloride. Effects of experimental conditions. Agronomie 1997, 17, 1-7.

(29) Sposito, G., The Surface Chemistry of Natural Particles. Oxford University Press: NY, 2004.

(30) Wolery, T. J. EQ3/6, A Software Package for Geochemical Modeling of Aqueous Systems: Package Overview and Installation Guide (Version 7.0); UCRL-MA--110662; Lawrence Livermore National Laboratory: Livermore, 1992.

(31) Qafoku, O.; Felmy, A., Development of accurate chemical equilibrium models for oxalate species to high ionic strength in the system: $\mathrm{Na}-\mathrm{Ba}-\mathrm{Ca}-\mathrm{Mn}-\mathrm{Sr}-\mathrm{Cl}-$ $\mathrm{NO}_{3}-\mathrm{PO}_{4}-\mathrm{SO}_{4}-\mathrm{H}_{2} \mathrm{O}$ at $25^{\circ} \mathrm{C}$. J. Solution Chem. 2007, 36, 81-95.

(32) Qafoku, N. P.; Qafoku, O.; Ainsworth, C. C.; Dohnalkova, A.; McKinley, S. G., Fesolid phase transformations under highly basic conditions. Appl. Geochem. 2007, 22, 2054 - 2064. 


\section{$\underline{\text { Tables and Figures }}$}

Table 1. Distribution of $\mathrm{Sr}, \mathrm{Ca}, \mathrm{Cs}, \mathrm{I}, \mathrm{Al}, \mathrm{Si}$ and $\mathrm{Fe}$ in the 6-mo reacted sediments.

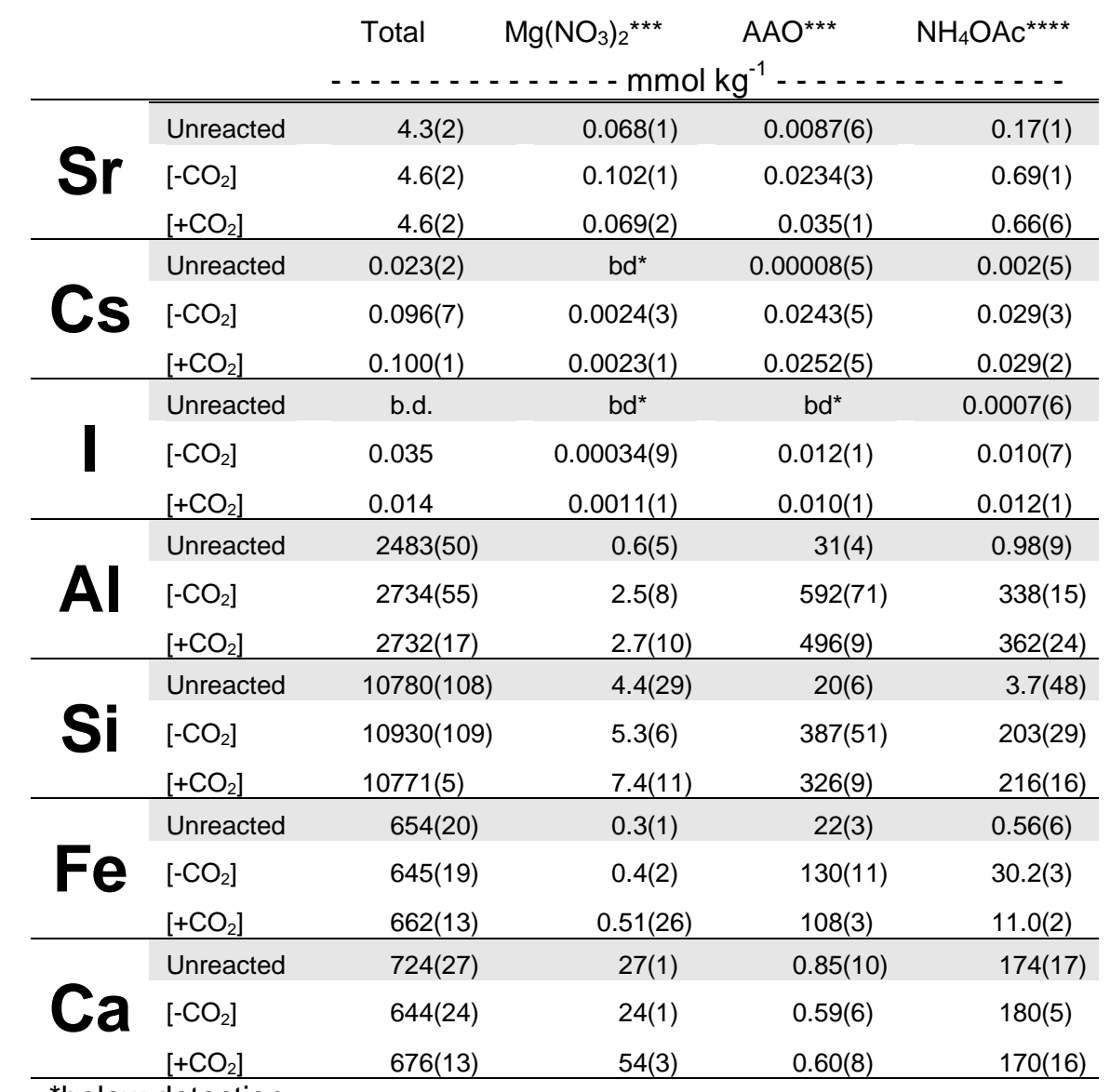

*below detection

${ }^{*}$ Errors are the standard deviation presented in concise form [e.g., $5.0(15)=5.0 \pm 1.5$ ], with $n=5$ except for 'total' values, in which $\mathrm{n}=2$.

*** Sequential extractions: $\mathrm{Mg}\left(\mathrm{NO}_{3}\right)_{2}$ followed by AAO (acid ammonium oxalate).

${ }^{* * * *} \mathrm{NH}_{4} \mathrm{OAc}$ (Ammonium acetate). This was a separate, non-sequential extraction. 

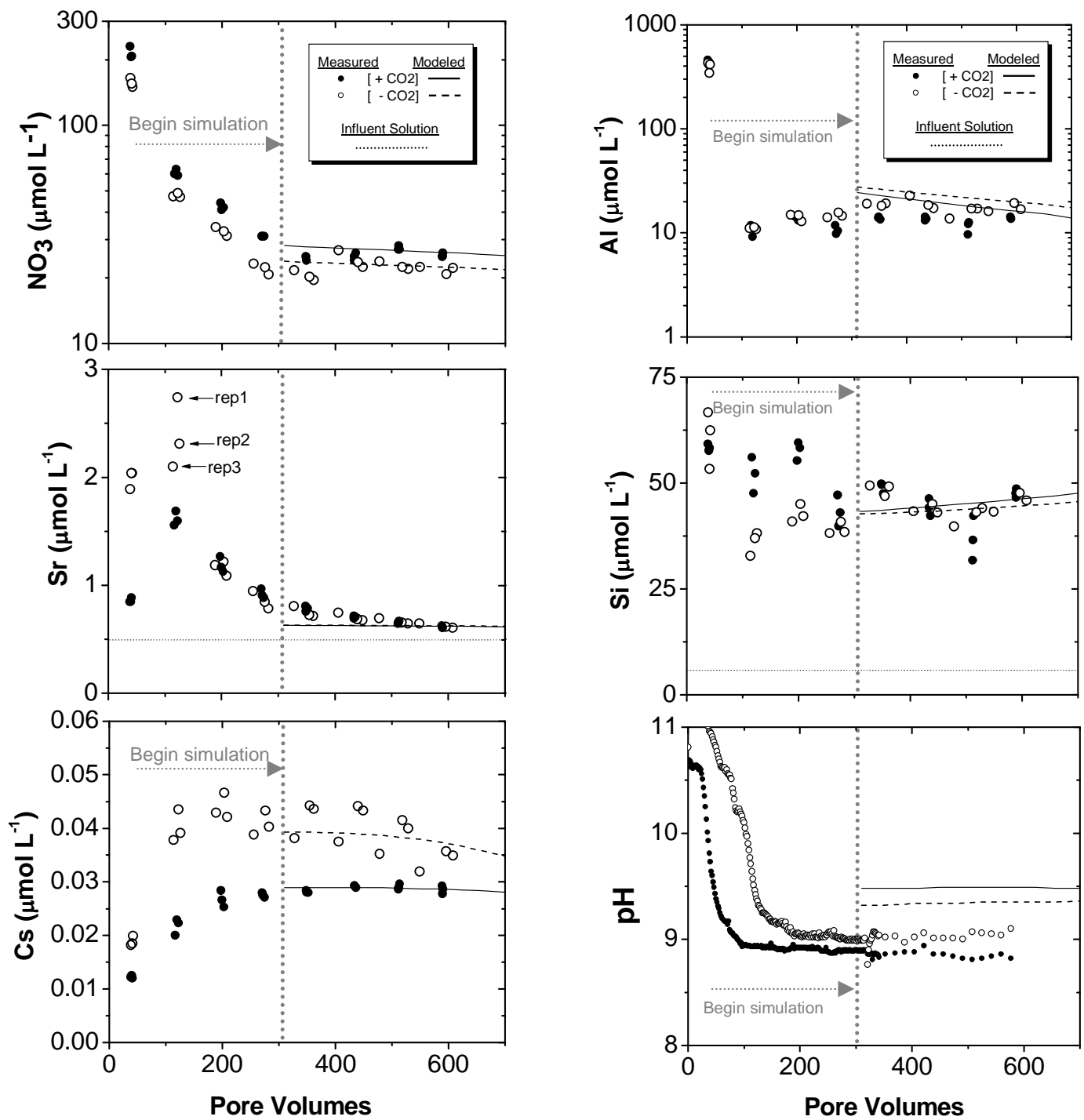

Figure 1. Pseudo steady-state desorption of $\mathrm{NO}_{3}, \mathrm{Sr}, \mathrm{Cs}, \mathrm{Al}, \mathrm{Si}$ and $\mathrm{pH}$ from hydroxideweathered sediment. Each data point represents $\sim 60$ pore volumes, 3 replicates are shown per treatment. Lines indicate kinetic simulations of Cs ion exchange and incongruent Sr-substituted feldspathoid dissolution coupled with generalized aluminum hydroxide and aluminosilicate precipitation. 

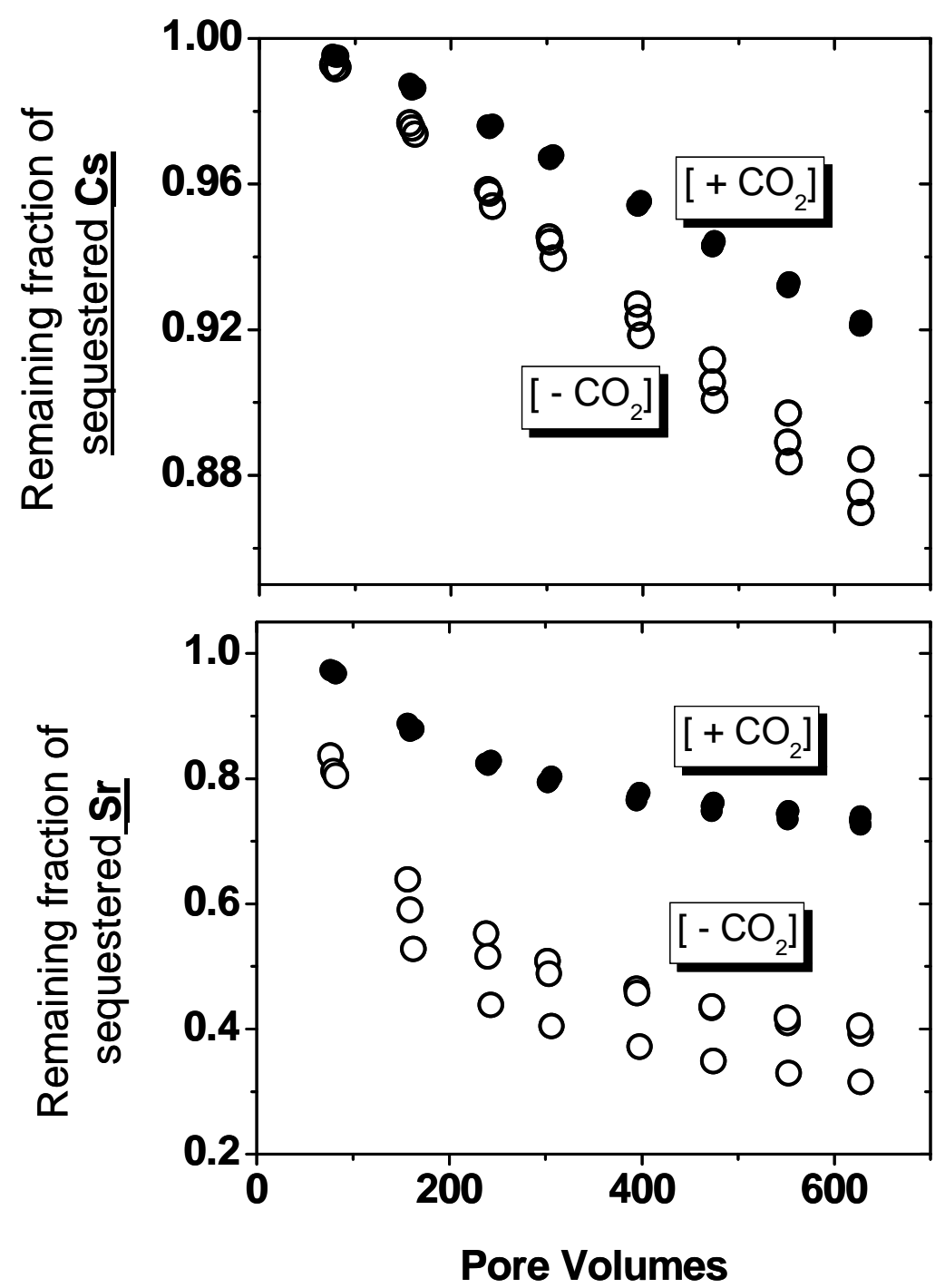

Figure 2. Remaining fraction of sorbed contaminant after leaching with background porewater. Each data point represents $\sim 60$ pore volumes, 3 replicates are shown per treatment. Note the difference in the $y$-axis between the two figures. 


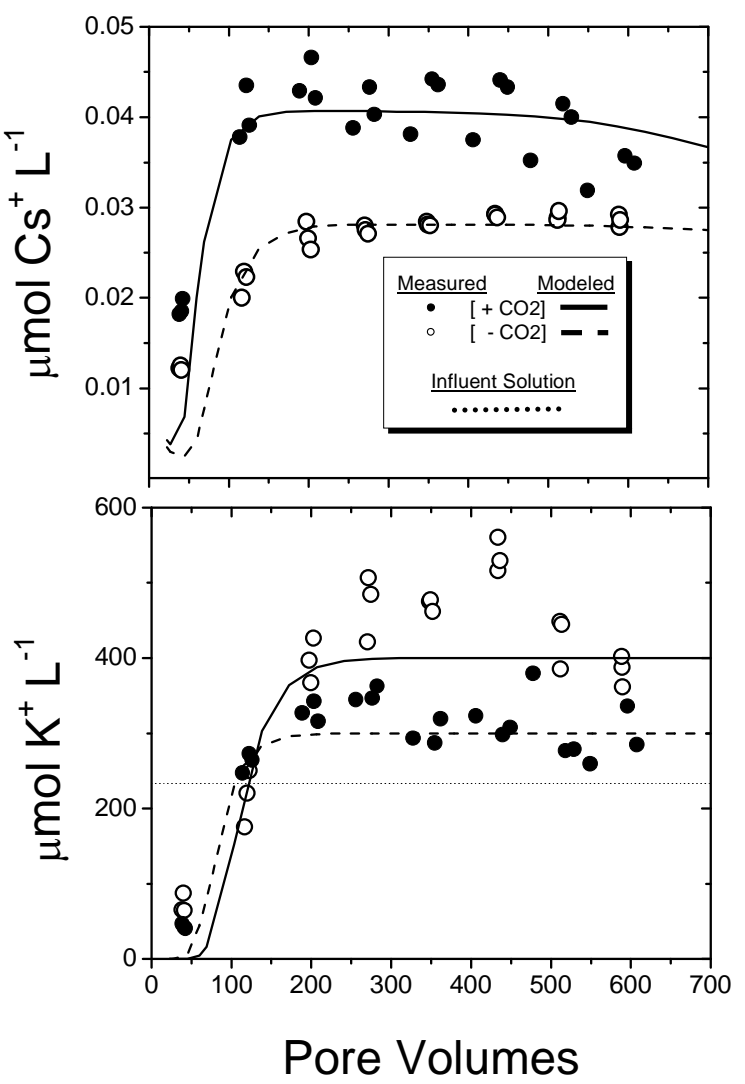

Figure 3. Model fitting of $\mathrm{K}^{+}$and $\mathrm{Cs}^{+}$breakthrough using the 3-site ion exchange model and column-weighted parameter set of Steefel et al (14) modified only by altering the planar CEC site density $\left[\left[-\mathrm{CO}_{2}\right]=5.8 \times 10^{-5} \mathrm{eq} \mathrm{g}^{-1},\left[+\mathrm{CO}_{2}\right]=7.5 \times 10^{-5} \mathrm{eq} \mathrm{g}^{-1}\right]$, and K-selectivity $\left[\mathrm{KX} 3+\mathrm{Cs}^{+}\right.$ $\leftarrow \mathrm{K}^{+}+\mathrm{CsX} 3$, modified $\log \mathrm{K}$ values to $0.879\left(\left[-\mathrm{CO}_{2}\right]\right)$ and $\left.0.929\left(\left[+\mathrm{CO}_{2}\right]\right)\right]$. $\mathrm{Cs}^{+}$loading on the exchange sites was ca. $0.03 \mu \mathrm{eq} \mathrm{g}^{-1}$ in both treatments. 